\title{
Co-infection of Parvovirus B19 and Plasmodium falciparum among Sickle Cell Disease Patients in Benin City, Nigeria
}

\author{
${ }^{1}$ Moses-Otutu, I. M., ${ }^{2}$ Okojie, R. O., ${ }^{1 *}$ Akinbo, F. O., and ${ }^{2}$ Eghafona, N. O. \\ ${ }^{1}$ Department of Medical Laboratory Science, School of Basic Medical Sciences, \\ University of Benin, Benin City, Nigeria \\ ${ }^{2}$ Department of Microbiology, Faculty of Life Sciences, \\ University of Benin, Benin City, Nigeria. \\ *Correspondence to: fgbengang@yahoo.com
}

\begin{abstract}
:
Background: Infections by parasites, bacteria, viruses such as human parvovirus B19 amongst others, have been widely reported as contributing to high prevalence of anaemia in many populations. This study was conducted to determine the co-infection of Plasmodium falciparum and human parvovirus B19 among sickle cell disease (SCD) patients in Benin City, Edo State, Nigeria. Methodology: A total of 400 participants consisting 300 SCD patients (134 males, 166 females) and 100 (38 males, 62 females) apparently healthy subjects with haemoglobin AA (which served as control) who were contacted in homes, schools and offices, were enrolled for the study. The age of the participants ranged from 1 to 54 years. Venous blood was collected for detection of $P$. falciparum using Giemsa stain while parvovirus B19 was detected with enzyme linked immunosorbent assay (ELISA). Full blood count was estimated using Sysmex KX-21N haematology auto-analyzer. Results: An overall prevalence of parvovirus B19 and $P$. falciparum co-infection observed among SCD patients in this study was $3.0 \%$ while single infection was $14.0 \%$ for $P$. falciparum and $26.7 \%$ for parvovirus B19. Religion was associated with 0 to 22 fold increased risk of acquiring co-infection of $P$. falciparum and parvovirus B19. Gender was significantly associated with $P$. falciparum infection $(p=0.0291)$ while tribal extraction, platelet index and seasonal variation were significantly associated with single parvovirus B19 or co-infection of $P$. falciparum and parvovirus B19 $(p<0.05)$. Conclusion: The provision of strict regulatory policy concerning the screening of whole blood or pooled plasma before the use of blood products and transfusion of SCD patients is advocated.
\end{abstract}

Keywords: parvovirus B19, Benin City, P. falciparum, sickle cell disease

Received September 24, 2018; Revised May 14, 2019; Accepted May 15, 2019

Copyright 2019 AJCEM Open Access. This article is licensed and distributed under the terms of the Creative Commons Attrition 4.0 International License (http://creativecommmons.org/licenses/by/4.0), which permits unrestricted use, distribution and reproduction in any medium, provided credit is given to the original author(s) and the source.

\section{Co-infection par le parvovirus B19 et Plasmodium falciparum chez des patients atteints de drépanocytose à Benin City, au Nigéria}

\footnotetext{
${ }^{1}$ Moses-Otutu, I. M., ${ }^{2}$ Okojie, R. O., ${ }^{1 *}$ Akinbo, F. O., and ${ }^{2}$ Eghafona, N. O.

${ }^{1}$ Département des sciences de laboratoire médical, École des sciences médicales de base, Université du Bénin, Benin City, Nigéria
} 


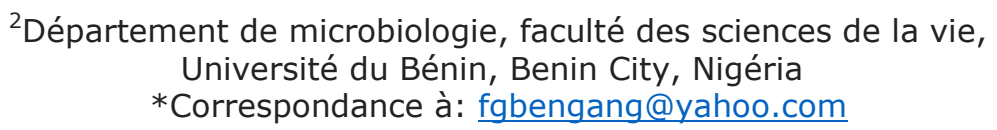

\section{Abstrait:}

Contexte: Il a été largement rapporté que les infections par des parasites, des bactéries, des virus tels que le parvovirus humain B19, contribuent à la prévalence élevée de l'anémie dans de nombreuses populations. Cette étude visait à déterminer la co-infection de Plasmodium falciparum et du parvovirus humain B19 chez des patients atteints de drépanocytose à Benin City, dans l'État d'Edo, au Nigéria.

Méthodologie: Un total de 400 participants comprenant 300 patients atteints de MCA (134 hommes, 166 femmes) et 100 (38 hommes et 62 femmes) des sujets apparemment en bonne santé avec I'hémoglobine AA (qui servait de contrôle) qui ont été contactés à la maison, dans les écoles et au bureau inscrit à l'étude. L'âge des participants allait de 1 à 54 ans. Le sang veineux a été recueilli pour la détection de $P$. falciparum à l'aide de la coloration de Giemsa, tandis que le parvovirus B19 a été détecté par un test d'immunosorbant lié à une enzyme (ELISA). La numération globulaire totale a été estimée à l'aide de l'auto-analyseur d'hématologie Sysmex KX-21N.

Résultats: La prévalence globale de la co-infection au parvovirus B19 et à $P$. falciparum observée chez les patients atteints de MCs dans cette étude était de 3,0\%, tandis que l'infection simple était de $14,0 \%$ pour $P$. falciparum et de $26,7 \%$ pour le parvovirus B19. La religion était associée à un risque accru de contracter la co-infection à $P$. falciparum et au parvovirus B19 de 0 à 22 fois plus élevé. Le sexe était significativement associé à l'infection à P. falciparum $(p=0,0291)$, tandis que l'extraction tribale, l'indice plaquettaire et la variation saisonnière étaient significativement associés à un parvovirus simple B19 ou à une co-infection à $P$. falciparum et au parvovirus B19 $(p<0,05)$ Conclusion: La mise en place d'une politique réglementaire stricte concernant le dépistage du sang total ou du plasma réuni avant l'utilisation du produit sanguin et la transfusion de patients atteints de MCS est recommandée.

Mots-clés: parvovirus B19, Benin City, Plasmodium falciparum, drépanocytose

\section{Introduction:}

Sickle cell disease (SCD) is known to consist of several disorders characterized by the presence of sickle haemoglobin (1). An estimated 300,000 children are born annually with SCD worldwide. This constitutes about $1 \%$ of the global population of SCD with over $75 \%$ in sub-Saharan Africa $(2,3)$. The high birth rate of SCD has highlighted the burden of SCD as a public health priority (3). However, there is a dearth of information on the burden of SCD to healthcare system and the significance on individual health (4).

Infection with Parvovirus B19 is common and can lead to a variety of clinical manifestations based on the immunological and haematological status of patients (5). Parvovirus B19 belongs to the family Parvoviridae which is subdivided into Parvovirinae and Densovirinae depending on the type of the infected host (6). Parvovirus B19 has specific tropism for erythroid progenitor cells and is capable of causing temporary infection of the bone marrow resulting in transient arrest of erythropoiesis (7). In patients with underlying haemolysis or haematological disorders such as sickle cell disease, acute B19 infection may cause transient aplastic anaemia, erythema infectiosum, hydrops fetalis, abrupt and severe anaemia due to failure of red blood cell production $(8,9,10)$. This virus is transmitted mainly via respiratory droplets but can be spread by contaminated blood, organ transplantation and transmission from mother to foetus (11).

Malaria is one of the major causes of morbidity and mortality in tropical and sub-tropical countries and is caused by the protozoan parasites of the genus Plasmodium with $P$. falciparum being the most virulent species (12). Malaria causes over 200 million cases of febrile illness out of which over a million children living in sub-Saharan Africa die annually $(13,14)$. 
It is widely seen as a major health challenge in Africans with SCD (15).

Parvovirus B19 infection can cause significant drop in haemoglobin concentration and reticulocyte count, conditions that could have serious consequences in patients particularly children with underlying malaria or those in malaria endemic regions (16). There are a number of studies that have emphasized the importance of co-infection with Parvovirus B19 in the etiology and pathogenesis of malaria in adults and children in nonsickle cell disease subjects (17-22). It is recognized that interactions between SCD and other infectious agents influence the health status of SCD patients. Parasites, bacteria, human parvovirus B19, and other infectious agents have been widely reported as important factors contributing to the high prevalence of anaemia in many populations $(23,24,25,26)$. There is however a dearth of information on the co-infection of $P$. falciparum and Parvovirus B19 among SCD patients in our environment. Against this background, this study was conducted to determine the co-infection of these pathogens among SCD patients in Benin City, Edo State, Nigeria.

\section{Materials and methods:}

\section{Study population}

The study was conducted between September 2017 and July 2018 at the Sickle Cell Center, Benin City, Edo State. The Sickle Cell Center has a referral status for the management of SCD patients Edo, Delta, and other neighbouring states. A total of 400 participants consisting of 300 SCD patients (134 males and 166 females) and 100 (38 males and 62 females) apparently healthy subjects with haemoglobin AA that were contacted in homes, schools and offices (served as control), were enrolled for the study. The age of the participants ranged from 1 and 54 years.

A well-structured questionnaire was administered to collect bio-data and other demographic information from the participants. Informed consent was obtained from all subjects or the parents or guardians in the case of children prior to specimen collection. The protocol for this study was approved by the Ethics and Research Committee of the Ministry of Health, Edo State, Nigeria.

\section{Specimen collection and processing}

Venous blood sample of about $8 \mathrm{ml}$ was collected from each participant, out of which $4.5 \mathrm{ml}$ was dispensed into ethylene diamine tetraacetic acid (EDTA) bottle and thoroughly mixed. The remaining $3.5 \mathrm{ml}$ sample was dispensed into plain container, allowed to clot, and serum separated for Parvovirus B19 analysis. Plasmodium falciparum was detected using a previously described method (27). Briefly, both thick and thin blood films were made from each blood specimen and allowed to air-dry. The blood films were stained in 3\% Giemsa stain for $30 \mathrm{~min}$, rinsed in tap water and allowed to air dry. The thick film was examined microscopically for presence of malaria parasite while the thin film was used to detect the species of Plasmodium using the oil immersion lens. A total of 200 fields per film were examined.

Full blood count was analyzed using a Sysmex KX-21N haematology auto-analyzer (Sysmex Corporation, Japan). Whole blood specimen dispensed into EDTA container was used. Anaemia was defined using the WHO criteria as haemoglobin concentration $<13 \mathrm{~g} / \mathrm{dl}$ for males and $<12 \mathrm{~g} / \mathrm{dl}$ for females (28). Parvovirus B19 was detected using enzyme-linked immunosorbent assay (ELISA) technique (Serion classic Parvovirus B19 IgG/IgM Wuzburg, Germany). Briefly, each sample was assayed according to the manufacturer's instruction using peroxidase-labeled rabbit anti-human IgM as the secondary antibody, tetramethyl benzidine as a substrate, and $1 \mathrm{M} \mathrm{H}_{2} \mathrm{SO}_{4}$ as a stop solution. The absorbance was read at 450 $\mathrm{nm}$ using a spectrophotometer. Index value between 10 and 15 was taken as reference value, with samples below the index range taken as negative while value 
above this range was taken as positive for IgM.

\section{Statistical analysis}

The data generated were analyzed using Chi square $\left(\mathrm{X}^{2}\right)$ test for frequency data whereas the odd ratio was calculated for each potential risk factor. The statistical software used was INSTAT (GraphPad Software Inc, La Jolla, CA. USA).

\section{Results:}

The prevalence of $26.7 \%$ for parvovirus B19, $14.0 \%$ for $P$. falciparum and $3.0 \%$ for co-infection of both pathogens were reported among the SCD patients, while prevalence of $4.7 \%$ for B19 infection only was observed in the control subjects. Gender was not significantly associated with prevalence of B19 infection or co-infection of B19 and $P$. falciparum $(p>0.05)$ (Table 1$)$. However, gender was significantly associated with the prevalence of $P$. falciparum infection among the SCD patients $(\mathrm{OR}=0.445 ; 95 \%$
$\mathrm{CI}=0.2186,0.9095 ; p=0.0291)$. The age of SCD patients was not associated with single infection as well as co-infection of B19 and $P$. falciparum in the study $(p>0.05)$. Educational status and religion were also not significantly associated with single and co-infection of B19 and $P$. falciparum $(p>0.05)$.

Tribal extraction was significantly associated with single and co-infection of B19 and $P$. falciparum with the Etsako subjects (Edo State) being the most infected $(53.9 \%)$ by B19 $(p=0.0065)$, Yoruba tribe had the highest prevalence of $P$. falciparum infection (45.5\%) $(p=0.0137)$ while the Hausa tribe had the highest prevalence $(20.0 \%)$ of coinfection of B19 and $P$. falciparum among the SCD patients $(p=0.0012)$. Seasonal variation was not significantly associated with prevalence of co-infection of B19 and $P$. falciparum $(p>0.05)$. However, rainy season significantly influenced the prevalence of B19 infection among SCD patients $\quad(\mathrm{OR}=2.077 ; \quad 95 \% \quad \mathrm{CI}=1.171$, $3.684 ; p=0.0144)$

Table 1: Factors associated with infection of parvovirus B19 and Plasmodium falciparum among sickle cell disease patients in Benin-City, Nigeria

\begin{tabular}{|c|c|c|c|c|c|}
\hline Factors & No tested & No infected (\%) & OR & $95 \% \mathrm{CI}$ & $p$ value \\
\hline \multicolumn{6}{|l|}{ Gender } \\
\hline Male & 134 & $36(26.9)$ & 1.019 & $0.6088,1.704$ & 1.000 \\
\hline Female & 166 & $44(67.7)$ & & & \\
\hline \multicolumn{6}{|l|}{ P. falciparum } \\
\hline Male & 134 & $12(9.0)$ & 0.4459 & $0.2186,0.9095$ & 0.0291 \\
\hline Female & 166 & $30(18.1)$ & & & \\
\hline \multicolumn{6}{|l|}{ Co-infection } \\
\hline Male & 134 & $5(3.7)$ & 1.570 & $0.4130,0.5967$ & 0.5194 \\
\hline Female & 136 & $4(2.4)$ & & & \\
\hline \multicolumn{6}{|l|}{ Age group (years) } \\
\hline $1-10$ & 89 & $14(15.7)$ & & & 0.0746 \\
\hline $11-20$ & 122 & $37(30.3)$ & & & \\
\hline $21-30$ & 53 & $16(30.2)$ & & & \\
\hline $31-40$ & 29 & $11(37.9)$ & & & \\
\hline $41 \&$ above & 7 & $2(28.6)$ & & & \\
\hline \multicolumn{6}{|l|}{ P. falciparum } \\
\hline $1-10$ & 89 & $14(15.7)$ & & & 0.0654 \\
\hline $11-20$ & 122 & $20(16.3)$ & & & \\
\hline $21-30$ & 53 & $4(7.5)$ & & & \\
\hline $31-40$ & 29 & $2(6.9)$ & & & \\
\hline $41 \&$ above & 7 & $2(28.6)$ & & & \\
\hline \multicolumn{6}{|l|}{ Co-infection } \\
\hline $1-10$ & 89 & $2(2.2)$ & & & 0.2357 \\
\hline $11-20$ & 122 & $3(2.5)$ & & & \\
\hline $21-30$ & 53 & $3(5.7)$ & & & \\
\hline
\end{tabular}




\begin{tabular}{|c|c|c|c|c|c|}
\hline $\begin{array}{l}31-40 \\
41 \& \text { above }\end{array}$ & $\begin{array}{c}29 \\
7\end{array}$ & $\begin{array}{c}0 \\
1(14.3)\end{array}$ & & & \\
\hline \multicolumn{6}{|l|}{ Educational status } \\
\hline Primary & 120 & $21(17.5)$ & & & \\
\hline Secondary & 98 & $32(32.7)$ & & & \\
\hline Tertiary & 82 & 27 (32.9) & & & \\
\hline \multicolumn{6}{|l|}{ P. falciparum } \\
\hline Primary & 120 & $16(13.3)$ & & & \\
\hline Secondary & 98 & $19(19.4)$ & & & \\
\hline Tertiary & 82 & $7(8.5)$ & & & \\
\hline \multicolumn{6}{|l|}{ Co-infection } \\
\hline Primary & 120 & $2(1.7)$ & & & \\
\hline Secondary & 98 & $4(4.1)$ & & & \\
\hline Tertiary & 82 & $3(3.7)$ & & & \\
\hline \multicolumn{6}{|l|}{ Religion } \\
\hline \multicolumn{6}{|l|}{ Parvovirus B19 } \\
\hline Christian & 282 & $74(26.2)$ & 0.7115 & $0.2577,1.964$ & 0.5828 \\
\hline Muslim & 18 & $6(33.3)$ & & & \\
\hline \multicolumn{6}{|l|}{ P. falciparum } \\
\hline Christian & 282 & $39(13.8)$ & 1.246 & $0.3447,4.505$ & 0.7257 \\
\hline Muslim & 18 & $3(16.7)$ & & & \\
\hline \multicolumn{6}{|l|}{ Co-infection } \\
\hline Christian & 282 & $9(3.2)$ & 1.285 & $0.7191,22.969$ & 1.000 \\
\hline Muslim & 18 & $6(33.3)$ & & & \\
\hline \multicolumn{6}{|l|}{ Tribe } \\
\hline \multicolumn{6}{|l|}{ Parvovirus B 19} \\
\hline Igbo & 48 & $14(29.2)$ & & & 0.0065 \\
\hline Yoruba & 11 & $4(36.4)$ & & & \\
\hline Ibibio & 21 & $8(38.1)$ & & & \\
\hline Bini & 164 & $31(18.9)$ & & & \\
\hline Esan & 20 & $7(35.0)$ & & & \\
\hline Etsako & 26 & $14(53.9)$ & & & \\
\hline Hausa & 10 & $2(20.0)$ & & & \\
\hline P. falciparum & 48 & $4(8.3)$ & & & 0.0137 \\
\hline Igbo & 11 & $5(45.5)$ & & & \\
\hline Yoruba & 21 & $2(9.5)$ & & & \\
\hline Ibibio & 164 & $19(11.6)$ & & & \\
\hline Bini & 20 & $4(20.0)$ & & & \\
\hline Esan & 26 & $6(23.1)$ & & & \\
\hline Etsako & 10 & 0 & & & \\
\hline \multicolumn{6}{|l|}{ Hausa } \\
\hline \multicolumn{6}{|l|}{ Co-infection } \\
\hline Igbo & 48 & $2(4.2)$ & & & 0.0012 \\
\hline Yoruba & 11 & $2(18.2)$ & & & \\
\hline Ibibio & 21 & 0 & & & \\
\hline Bini & 164 & $2(1.2)$ & & & \\
\hline Esan & 20 & 0 & & & \\
\hline Etsako & 26 & $1(3.85)$ & & & \\
\hline Hausa & 10 & $2(20.0)$ & & & \\
\hline \multicolumn{6}{|l|}{ Season } \\
\hline \multicolumn{6}{|l|}{ Parvovirus B19 } \\
\hline Rainy & 190 & $60(31.6)$ & 2.077 & $1.171,3.684$ & 0.0144 \\
\hline \multirow{2}{*}{\multicolumn{6}{|c|}{ P. falciparum }} \\
\hline & & & & & \\
\hline Rainy & 190 & $31(16.3)$ & 1.755 & $0.8436,3.650$ & 0.1669 \\
\hline \multirow{2}{*}{\multicolumn{6}{|c|}{ Co-infection }} \\
\hline & & & & & \\
\hline Rainy & 190 & $7(3.7)$ & 2.066 & $0.4213,10.127$ & 0.4939 \\
\hline Dry & 110 & $2(1.8)$ & & & \\
\hline
\end{tabular}


Table 2: Effect of haematological factors on co-infection of Parvovirus B19 and Plasmodium falciparum among Sickle Cell Disease patients in Benin-City, Nigeria

\begin{tabular}{|c|c|c|c|c|c|}
\hline Factors/Patients & No tested & No infected & OR & $95 \% \mathrm{CI}$ & $p$ value \\
\hline \multicolumn{6}{|l|}{ Transfusion } \\
\hline Yes & 176 & $46(26.1)$ & 0.9367 & $0.5577,1.573$ & 0.8946 \\
\hline No & 124 & $34(27.4)$ & & & \\
\hline \multicolumn{6}{|l|}{ P. falciparum } \\
\hline Yes & 176 & $26(14.8)$ & 1.170 & $0.5985,2.287$ & 0.7363 \\
\hline No & 124 & $16(12.9)$ & & & \\
\hline \multicolumn{6}{|l|}{ Co-infection } \\
\hline Yes & 176 & $6(3.4)$ & 1.424 & $0.3490,5.806$ & 0.7406 \\
\hline No & 124 & $3(2.4)$ & & & \\
\hline \multicolumn{6}{|l|}{ Anaemia } \\
\hline \multicolumn{6}{|l|}{ Parvovirus B19 } \\
\hline Anaemia & 292 & $76(26.0)$ & 0.3519 & $0.08584,1.442$ & 0.2160 \\
\hline No anaemia & 8 & $4(50.0)$ & & & \\
\hline \multicolumn{6}{|l|}{ P. falciparum } \\
\hline Anaemia & 292 & $40(13.7)$ & 0.4762 & $0.09282,2.443$ & 0.3110 \\
\hline No anaemia & 8 & $2(25.0)$ & & & \\
\hline \multicolumn{6}{|l|}{ Co-infection } \\
\hline Anaemia & 292 & $8(2.7)$ & 0.1972 & $0.02162,1.798$ & 0.2186 \\
\hline No anaemia & 8 & $1(12.5)$ & & & \\
\hline \multicolumn{6}{|c|}{ Platelet count (cells $/ \mu \mathrm{L}$ ) } \\
\hline \multicolumn{6}{|c|}{ Parvovirus B19 } \\
\hline$<150,000$ & 24 & $6(25.0)$ & 0.9099 & $0.3478,2.381$ & 1.000 \\
\hline$\geq 150,000$ & 276 & $74(26.8)$ & & & \\
\hline \multicolumn{6}{|l|}{ P. falciparum } \\
\hline$<150,000$ & 24 & $4(16.7)$ & 1.253 & $0.4058,3.866$ & 0.7576 \\
\hline$\geq 150,000$ & 276 & $38(13.8)$ & & & \\
\hline \multicolumn{6}{|l|}{ Co-infection } \\
\hline$<150,000$ & 24 & $4(16.7)$ & 10.840 & $2.696,43.580$ & 0.0031 \\
\hline$\geq 150,000$ & 276 & $5(1.8)$ & & & \\
\hline
\end{tabular}

History of blood transfusion was not significantly associated with the prevalence of single or co-infection of B19 and $P$. falciparum among the SCD patients $(p>0.05)$ (Table 2). Anaemia was also not significantly associated with single or coinfection of B19 and $P$. falciparum $(p>0.05)$. However, platelets count was significantly associated with co-infection of B19 and P. falciparum among the SCD patients especially with platelet count of $<150$ cells $/ \mu$ L (OR $0.840,95 \%$ CI 2.696 , 43.580, $p=0.0031$ ).

\section{Discussion:}

Sickle cell disease runs a variable clinical course ranging from mild disease to severe life threatening complications (29). Individuals with SCD are known to be susceptible to infectious agents (30, 31). This study examined parvovirus B19 and $P$. falciparum infections in SCD patients in our locality. To our knowledge, this is the first study on this in Edo State. It has been hypothesized that depression of cell-mediated immunity in $P$. falciparum infection might favour co-infection with opportunistic pathogens including Parvovirus B19 (32). An overall prevalence of parvovirus $\mathrm{B} 19$ and $P$. falciparum coinfection observed in this study was $3.0 \%$ whereas the single infection was $14.0 \%$ for $P$. falciparum and $26.7 \%$ for B19. The prevalence of co-infection of B19 and $P$. falciparum observed in our study is lower than the $14.21 \%$ observed in non-SCD patients in Gabon (33). This difference in prevalence rates may be related to population studied, geographical location and seasonal variation.

Gender was not significantly associated with co-infection of $P$. falciparum and B19 although it was significantly associated with $P$. falciparum infection among the SCD patients. Similarly, age was not significantly associated with single infection or co- 
infection of B19 and $P$. falciparum among the SCD patients. These observations in our study may indicate adherence of SCD patients or their parents or guardians or relatives to health information that can aid quality of life of SCD patients, usually provided by their clinicians.

Patients or individuals living in malaria endemic regions are known to be at increased risk of serious complications with co-infection of $\mathrm{B} 19$ and $P$. falciparum (34). In individuals with SCD who have tolerated chronic anaemia, there could be rapid worsening of the anaemia, which can present as an emergency (4). Under these circumstances, anaemia becomes life threatening and requires prompt treatment with blood transfusion to reduce the deleterious effects of haemoglobin S and improve outcome (4). Parvovirus $\mathrm{B} 19$ and $P$. falciparum are easily transmitted by blood transfusion and transfusion with plasma derived products (35). SCD patients are known to be at high risk of transfusion-transmissible infections since they receive frequent, often unplanned, emergency blood transfusion $(36,37)$. Surprisingly, history of blood transfusion was not significantly associated with single and co-infection of B19 and $P$. falciparum among our SCD patients. The reason for this finding is unclear.

In this study, religion and educational status of our SCD patients were not significantly associated with single or co-infection of B19 and $P$. falciparum. However, tribal extraction was significantly associated with single or coinfection of B19 and $P$. falciparum among the SCD patients, with the SCD patients of Etsako tribe in Edo State having the highest prevalence (53.9\%) of B19 infection, the Yoruba tribe had the highest prevalence $(45.5 \%)$ of $P$. falciparum while the Hausa tribe had the highest prevalence of co-infection (20.0\%) of B19 and $P$. falciparum. The reasons for these tribal differences remain to be elucidated. Seasonal variation in prevalence of malaria is well established with highest prevalence during the rainy season (38, 39). Surprisingly, seasonal variation was not significantly associated with prevalence of $P$. falciparum malaria and coinfection of B19 and $P$. falciparum in our SCD patients, but was significantly associated with the prevalence of B19 infection, with highest prevalence $(31.6 \%)$ in the raining season compared to the dry season $(18.2 \%)(p=0.0144)$.

Both immunological and nonimmunological destructions of platelets have been implicated to cause thrombocytopenia, resulting from consumptive coagulopathy, platelet sequestration in spleen, antibody mediated platelet destruction and oxidative stress. Platelet may also act as cofactor to trigger severe malaria, and abnormalities in platelet structure and function have been described as a consequence of malaria and in rare instances, platelets can be invaded by malaria parasites $(40,41,42)$. Previous studies have indicated the involvement of white cells and platelets in single infection and co-infection of B19 and $P$. falciparum $(43,44,45,46)$. In our study, platelet index was not significantly associated with prevalence of single infection of $\mathrm{B} 19$ or $P$. falciparum. However, platelet count of $<150$ cells $/ \mu L$ was a risk factor as it was associated with a 2 to 43 fold increased risk of acquiring co-infection of $\mathrm{B} 19$ and $P$. falciparum among our SCD patients. In addition, platelet index was significantly associated with the prevalence of co-infection of B19 and $P$. falciparum among the SCD patients. Our findings are in agreement with the previous report of Girei et al. among SCD patients with B19 infection in Jos (46).

Parvovirus B19 and P. falciparum co-infections have been reported to cause severe anaemia, which can be fatal particularly among SCD patients $(11,47$, 48). Parvovirus B19 causes anaemia because it selectively inhibits and lyse actively replicating erythroid progenitor cells $(9,49)$ which are targets of $P$. falciparum, co-infection of the two pathogens therefore result in severe anaemia (19, 50, 51). Surprisingly, anaemia was not significantly associated with single infection or co-infection of 
parvovirus B19 and $P$. falciparum among our SCD patients. Our finding is consistent with the previous study of Toan et al. (33) who also did not observe significant difference in haemoglobin concentration among non-SCD patients with coinfections of B19 and $P$. falciparum. The reason for this finding remains unclear.

\section{Conclusion:}

An overall prevalence of parvovirus B19 and $P$. falciparum co-infection of $3.0 \%$ was observed in our SCD patients in this study, and single infection of $14.0 \%$ for $P$. falciparum and $26.7 \%$ for B19 were similarly reported. While gender was significantly associated with $P$. falciparum infection among our SCD patients, tribal extraction, platelet index and seasonal variation were significantly associated with single parvovirus B19 infection or co-infection of B19 and $P$. falciparum. The provision of strict regulatory policy concerning the screening of whole blood or pooled plasma before transfusion of blood or blood products in SCD patients is advocated.

\section{Acknowledgements:}

The authors acknowledge with thanks the Sickle Cell Center and the Ministry of Health, Edo State for the permission to carry out this study. The participants are equally acknowledged.

\section{References:}

1. Onwubalili, J. K. Sickle cell anaemia and reincarnation beliefs in Nigeria. Lancet. 1983; 2 (8364): 1423.

2. Diallo, D., and Tchernia, G. Sickle cell disease in Africa. Curr Opin Hematol. 2002; 9 (2):111-116

3. World Health Organization. Management of Birth Defects and Haemoglobin Disorders: Report of a Joint WHO-March of Dimes Meeting. Geneva, Switzerland: World Health Organization; 2006.

4. Makani, J., Ofori-Acquah, S. F., Nnodu, O., Wonkam, A., and Ohene-Frempong, K. Sickle Cell Disease: New Opportunities and Challenges in Africa. Scientific World J. 2013; 1-16. http://dx.doi.org/10.1155/2013/193252

5. Plummer, F. A., Hammond, G. W., Forward, K., Sekla, L., Thompson, L. M., Jones, S. E.,
Kidd, I. M., and Anderson, M. J. An erythema infectiosum-like illness caused by human parvovirus infection. N Engl J Med. 1985; 313: 74-79

6. International Committee on Taxonomy of Viruses (ICTV). Virus taxonomy: 2007 release. Virology division, IUMS. 2007. Available at http://www.ictvonline.org

7. Ozawa, K., Kurtzman, G., and Young, N. Replication of the B19 parvovirus in human bone marrow cell culture. Science. 1986; 233: 883-886.

8. Serjeant, G. R., Serjeant, B. E., Thomas, P. W., Anderson, M. J., Patou, G., and Pattison, J. R. Human parvovirus infection in homozygous sickle cell disease. Lancet. 1993; 341 (8855): 1237-1240

9. Young, N. S., and Brown, K. E. Parvovirus B19. N Engl J Med. 2004, 350 (6): 586597.

10. Carzavec, D., Gacina, P., Vasilj, A., Katovic, S. K. Aplastic crisis induced by human parvovirus B19 as an initial presentation of hereditary spherocytosis. Coll Antropol. 2010; 34: 619-621.

11. Heegaard, E. D., and Brown, K. E: Human parvovirus B19. Clin Microbiol Rev. 2002; 15 (3):485-505.

12. Koukouikila-Koussounda, F., Ntoumi, F., Ndounga, M., Tong, H.V., Abena, A. A., and Velavan, T. P. Genetic evidence of regulatory gene variants of the STAT6, IL10R and FOXP3 locus as a susceptibility factor in uncomplicated malaria and parasitaemia in Congolese children. Malar J. 2013; 12: 9

13. Murray, C. J., and Lopez, A. D. Global mortality, disability, and the contribution of risk factors: Global Burden of Disease Study. Lancet. 1997; 349:1436-1442. 14. Snow, R. W., Craig, M. H., Newton, C. R. J. C., and Steketee, R. W. The public health burden of $P$. falciparum malaria in Africa: deriving the numbers. Bethesda, MD: Fogerty International Center, National Institutes of Health, 2003.

15. Aidoo, M., Terlouw, D. J., Kolczak, M., McElroy, P. D., ter Kuile, F. O., Kariuki, S., Nahlen, B. L., La, A. A., and Udhayakumar, V. Protective effects of the sickle cell gene against malaria morbidity and mortality. Lancet. 2002; 359 (9314):1311-1312.

16. Pasvol, G. Parvovirus infection, malaria and anemia in the tropics - a new hidden enemy. J Infect Dis. 2006; 194: 141-142

17. Jones, P. H., Pickett, L. C., Anderson, M. J., and Pasvol, G. Human parvovirus infection in children and severe anaemia seen in an area endemic for malaria. J Trop Med Hyg. 1990; 93 (1): 67-70.

18. Lortholary, O., Eliaszewicz, M., Dupont, B., and Courouce, A. M. Parvovirus B19 infection during acute Plasmodium falciparum malaria. Eur J Haematol. 1992, 49 (4): 219.

19. Wildig, J., Mueller, I., Kiniboro, B., Maraga, 
S., Siba, P., and Cossart, Y. Seroprevalence of antibodies to parvovirus B19 among children in Papua New Guinea. Am J Trop Med Hyg. 2007; 77 (2): 354-357.

20. Bonsch, C., Kempf, C., Mueller, I., Manning, L., Laman, M., Davis, T. M., and Ros, C. Chloroquine and its derivatives exacerbate B19-associated anemia by promoting viral replication. PLoS Negl Trop Dis. 2010; 4 (4): e669

21. Ingrassia, F., Gadaleta, A., Maggi, P., and Pastore, G. Plasmodium falciparum malaria and Parvovirus B19; a case of acute Coinfection. BMC Infect Dis. 2010; 10:87

22. Duedu, K. O., Sagoe, K. W., Ayeh-Kumi, P. F., Affrim, R. B., Adiku, T., and Huat, L. B. The effects of co-infection with human parvovirus B19 and Plasmodium falciparum on type and degree of anaemia in Ghanaian children. Asian Pac J Trop Biomed. 2013; 3 (2): 129-139.

23. Dreyfuss, M. L., Stoltzfus, R. J., Shrestha, J. B., Pradhan, E. K., LeClerq, S. C., Khatry, S. K., Shrestha, S. R., Katz, J., Albonico, M., and West, K. P. Jr. Hookworms, malaria and vitamin A deficiency contribute to anemia and iron deficiency among pregnant women in the plains of Nepal J Nutr. 2000; 130: 2527-2536

24. Brooker, S., Akhwale, W., Pullan, R., Estambale, B., Clarke, S. E., Snow, R. W. and Hotez, P. J. Epidemiology of plasmodium-helminth co-infection in Africa: populations at risk, potential impact on anemia, and prospects for combining control. Am J Trop Med Hyg. 2007; 77: 8898.

25. van Hensbroek, B. M., Calis, J. C., Phiri, K. S., Vet, R., Munthali, F., Kraaijenhagen, R., van den Berg, H., Faragher, B., Bates, I., and Molyneux, M. E. Pathophysiological mechanisms of severe anaemia in Malawian children. PLoS One. 2010; 5: e12589.

26. Carraturo, A., Catalani, V., Ottaviani, D. Menichelli, P., Rossini, M., Terella, D., and Biondi, B. Parvovirus B19 infection and severe anemia in renal transplant recipients. Sci. World J. 2012; 2012: 102829.

27. Cheesbrough, M. District Laboratory Practice in Tropical Countries. 2nd Edition, Cambridge University Press, Cambridge, 1999.

28. Beutler, E., Waalen, J. The definition of anaemia: what is the lower limit of normal of the blood haemoglobin concentration? Blood. 2006; 107: 1747-1750

29. Weatherall, D. J. Genetic disorders of Haemoglobin. In: Hoffbrand, A. V., Lewis, S. M., and Tuddenham, E. G. D. (eds). Postgraduate Haematology $4^{\text {th }}$ edition. Great Britain. Butterworth-Heinemann, 1999; 91119

30. West, T. B., West, D. W, and OheneFrempong, K. The presentation, frequency, and outcome of bacteremia among children with sickle cell disease and fever. Pediatr Emerg Care. 1994; 10 (3): 141-143.

31. Wierenga, K. J. J., Hambleton, I. R., Wilson, R. M., Alexander, H., Serjeant, B. E., and Serjeant, G. R. Significance of fever in Jamaican patients with homozygous sickle cell disease. Arch Dis Childhood. 2001; 84 (2): 156-159

32. Ho, M., Webster, H. K., Looareesuwan, S., Supanaranond, W., Phillips, R. E, Chanthavanich, P., and Warrell, D. A. Antigen-specific immunosuppression in human malaria due to Plasmodium falciparum. J Infect Dis. 1986; 153: 763771

33. Toan, N. L., Sy, B. T, Song, L. H., Luong, H. V., Binh, N. T., Binh, V. Q., Kandolf, R., Velavan, T. P., Peter, G., Kremsner, P. G., and Bock, C-T. Co-infection of human parvovirus B19 with Plasmodium falciparum contributes to malaria disease severity in Gabonese patients. BMC Infect Dis. 2013; 13: $375-384$

34. Slavov, S. N., Kashima, S., Silva-Pinto, A. C., and Covas, D. T. Genotyping of human parvovirus B19 among Brazilian patients with hemoglobinopathies. Can J Microbiol. 2012; 58: 200-205.

35. Modrow, S., Wenzel, J., Schimanski, S., Schwarzbeck, J., Rothe, U., Oldenburg, J., Jilg, W., and Eis-Hubinger, A. Prevalence of nucleic acid sequences specific for human parvoviruses, hepatitis $A$ and hepatitis $E$ viruses in coagulation factor concentrates. Vox Sang. 2010; 100: 351-358

36. Hassan, H., Hasan S., Giday, S., Alamgir, L., Banks, A., and Frederick, W. Hepatitis C virus in sickle cell disease. Journal of the National Medical Association. 2003; 95 (10): 939-942.

37. Tshilolo, L. M., Mukendi, R. K., and Wembonyama, S. O. Blood transfusion rate in Congolese patients with sickle cell anemia. Indian J Pediatr. 2007; 74:735-738

38. Riley, E. M., Wagner, G. E., Akanmori, B. D., and Koram, K. A. Review Do maternally acquired antibodies protect infants from malaria infection? Parasite Immunol. 2001; 23 (2): 51-59.

39. Achidi, E. A., Apinjoh, T. O., Mbunwe, E., Besingi, R., Yafi, C., Wenjighe, A. N., Ajua, A., and Anchang, J. K. Febrile status, malarial parasitaemia and gastro-intestinal helminthiases in school children resident at different altitudes, in south-western Cameroon. Ann Trop Med Parasitol. 2008; 102 (2): 103-118

40. Jadhav, U. M., Patkar, V. S., and Kadam, N. N. Thrombocytopenia in malaria-correlation with type and severity of malaria. J Assoc Physicians India. 2004; 52: 615-618. 41. Rasheed, A., Saeed, S., and Khan, S. A. Platelet counts in malaria. Pak J Phytopathopathol. 2008; 19: 86-88 42. Faseela, T. S., Roche, Anita, K. B., Malli, C. S., and Rai, Y. Diagnostic value of platelet 
count in malaria. J Clin Diagn Res. 2011; 5: 464-466

43. Doran, H. M., and Teall, A. J. Neutropenia accompanying erythroid aplasia in human parvovirus infection. $\mathrm{Br}$ J Haematol. 1988; 69: 287-288

44. Inoue, S., Kinra, N. K., Mukkamala, S. R., and Gordon, R. Parvovirus B19 infection: aplastic crisis, erythema infectiosum and idiopathic thrombocytopenic purpura.

Pediatr Infect Dis J. 1991; 10: 251-253 Olumese, P. E., Adeyemo, A. A., Ademowo, O. G., Gbadegesin, R. A., Sodeinde, O., and Walker, $\mathrm{O}$. The clinical manifestations of cerebral malaria among Nigerian children with the sickle cell trait. Ann Trop Paediatr. 1997; 17: 141-145

46. Girei, A. I., Alao, O. O., Joseph, D. E., Damulak, D. O., Banwat, E. B., Nwadioha, S. I., and Jombo, G. T. A. Human parvovirus B19 infection among children with sickle cell anaemia in Jos, North
Central Nigeria. Journal of Hainan Medical University. 2010; 10.

47. Broliden, K., Tolfvenstam, T., and Norbeck, O. Clinical aspects of parvovirus B19 infection. J Intern Med. 2006; 260: 285304

48. Booth, C., Inusa, B., and Obaro, S. K. Infection in sickle cell disease. A review. Intern J Infect Dis. 2010; 14: 2-12.

49. Brown, K. Anaemia, parvovirus, and malaria. Lancet. 2006; 368 (9537): 714716.

50. Scarlata, F., Gianelli, E., Miceli, S., Galimberti, L., and Antinori, S. Acute parvovirus B19 infection and anemia during Plasmodium falciparum malaria. Clin Infect Dis. 2002; 35 (11): 1449-1451.

51. Gupta, R., and Singh, T. Parvovirus B19 coinfection with falciparum malaria: a cause of severe anemia. Haematologica. 2005; 90 (12): ECR41 